\title{
Features of Distance Education in Ukraine during the Covid-19 Pandemic: Problems and Prospects
}

\author{
Kurok $\mathrm{O}^{1}$, Lucenko G ${ }^{1, *}$, Povstyn $\mathrm{O}^{2}$, Lutsenko $\mathrm{O}^{3}$ \\ ${ }^{1}$ Oleksandr Dovzhenko Hlukhiv National Pedagogical University, Ukraine \\ ${ }^{2}$ Department of Law and Management in the Field of Civil Defense, Lviv State University of Life Safety, Ukraine \\ ${ }^{3}$ Department Theory and Methodics of Teaching Natural Sciences, Oleksandr Dovzhenko Hlukhiv National Pedagogical University, \\ Ukraine
}

Received July 28, 2020; Revised September 1, 2020; Accepted September 29, 2020

\section{Cite This Paper in the following Citation Styles}

(a): [1] Kurok O, Lucenko G, Povstyn O, Lutsenko O, "Features of Distance Education in Ukraine during the Covid-19 Pandemic: Problems and Prospects," Universal Journal of Educational Research, Vol. 8, No. 11, pp. 5498 - 5504, 2020. DOI: 10.13189/ujer.2020.081153.

(b): Kurok O, Lucenko G, Povstyn O, Lutsenko O (2020). Features of Distance Education in Ukraine during the Covid-19 Pandemic: Problems and Prospects. Universal Journal of Educational Research, 8(11), 5498 - 5504. DOI: 10.13189/ujer.2020.081153.

Copyright $\odot 2020$ by authors, all rights reserved. Authors agree that this article remains permanently open access under the terms of the Creative Commons Attribution License 4.0 International License

\begin{abstract}
Our study reveals the peculiarities of the educational process in Ukraine after the introduction of distance learning related to the Covid-19 pandemic. The study was conducted based on two leading educational institutions in Ukraine. We have established that the introduction of distance education both in the world and in Ukraine has its pros and cons. In particular, it depends primarily on the initiative of the teacher to implement such technologies, as well as on the willingness of students to use them and the technical ability of both parties to use these technologies (because our country has faced the problem of Internet coverage). We found that in the era of information technology, the level of communication, both interpersonal and with students, has not changed among the respondents. It is established that almost all teachers who took the survey believe that distance education does not provide students with practical skills, competencies after graduation. Distance education from the point of view of management and administrative activity is more expedient, it gives educational institutions more decentralization and optimization in work.
\end{abstract}

Keywords Covid-19, Education, Information Technologies, Knowledge, University, Distance Education

\section{Introduction}

Today, the world's leading universities are thinking about the problem of transforming education after quarantine and how to return students to their campuses. Ukraine is no exception in this situation [2].

In the context of the global coronavirus pandemic 2019-nCoV and the spread of infection throughout Ukraine, it is extremely important to ensure a quality educational process [12].

Therefore, all educational institutions in Ukraine understand how important it is to minimize the spread of the new virus, which today is achieved primarily by limiting social contacts, reducing the time spent in crowded places, including public transport. To this end, universities are taking all the necessary measures. Students and all those who are not directly involved in performing the necessary production functions have completely stopped attending educational buildings. Employees of departments, chairs, deans' offices/directorates, other structural subdivisions, and services are transferred to the mode of remote work as much as possible. Teachers are recommended to perform all the necessary educational, scientific, methodological activities in terms of remote access.

However, this does not mean that work at universities has stopped. On the contrary, right now, in the new difficult 
conditions, it is especially important to maintain the full capacity of educational institutions, to ensure the implementation of all major tasks assigned to universities by society. We want to emphasize that all the main functions of universities are performed considering the peculiarities of the quarantine period. The administrative and economic part maintains in good condition the territory, educational buildings, and dormitories of universities. Accounting and planning and finance departments provide financial activities, timely accrual, and payment of salaries and scholarships. The human resources department performs all the necessary procedures related to the movement of personnel. The educational and methodical department coordinates the work on the organization of distance learning of students. The library continues to work for its users online. The dormitory department provides the mode of operation of the university dormitories with the necessary quarantine restrictions, as dormitories are inhabited by students who are unable to leave them (for example, foreign students or students deprived of parental care). All this is provided by a flexible mode of operation of structural units, in accordance with the current situation, which is changing very dynamically.

And most importantly - the educational process in universities is not interrupted but continues in the form of distance learning.

The coronavirus pandemic in Ukraine caused technical discomfort to most participants in the educational process. This has forced everyone to start using modern technologies of the educational process, whether they like it or not.

And this direct practical experience allowed them to master these skills quite skillfully. In fact, technology has long been an integral part of our lives, so educators need to be able to use this handy tool, no matter what mode they are learning. Because now, distance learning is due to circumstances, although it increases the availability of education, and blended learning - a combination of distance and full-time forms - may well become our future. However, to do this, today we must actively work on the lessons learned and ensure the quality of such education.

It is the above that prompted us to our study. Therefore, the aim was to investigate the peculiarities of the introduction of distance education in Ukraine during the Covid-19 pandemic, what problems and prospects it has.

\section{Methods}

Our study covered two leading educational institutions in Ukraine, namely:

Lviv State University of Life Safety (Lviv, Western Ukraine) and Oleksandr Dovzhenko Hlukhiv National Pedagogical University (Hlukhiv, Sumy Region, Northern Ukraine). Both educational institutions are geographically located on the map of Ukraine directly near the borders of other countries. Also, these educational institutions have different areas of student training, namely: Oleksandr Dovzhenko Glukhiv National Pedagogical University is a classic pedagogical university that trains educators of preschool educational institutions and teachers. Lviv State University of Life Safety has a non-pedagogical direction of training (civil defense, management, and administration, etc.).

We developed a questionnaire for 14 questions, the main essence of which is the features of distance education in the educational institution, what technical means were used more by teachers, gender, etc.
1) Name of your educational institution
2) Your position
- teacher
- docent
- professor
- other
3) Age
- $\quad 20-30$ years
- $31-40$ years
- $41-50$ years
- 51-60 years
- 61-70 years

4) Become

- a woman

- a man

5) How did the level of your communication with colleagues change during the COVID19 pandemic?

- increased

- remained at the previous level

- decreased

6) How did the level of your communication with students change during the COVID19 pandemic?

- increased

- remained at the previous level

- decreased

7) What changes took place in the management system of your school during the COVID19 pandemic?

- $\quad$ became more centralized

- optimization took place

- decentralization took place

8) Assess the level of your psychological comfort when working in distance education?

- comfortable

- uncomfortable

9) Are you satisfied with the quality of Internet communication provided by your provider?

- yes

- No

- partially

- $\quad$ I use 3G / 4G

10) What communication tools and technologies do you use during the COVID19 pandemic?

\section{- ZOOM}


- $\quad$ Google services

- Email

- Viber

- Other

11) Assess the level of difficulty in mastering distance education technologies?

- $\quad$ exceedingly difficult

- not difficult

- I have been using these technologies for a long time

12) Do you think that distance education is able to provide quality opportunities for practical skills and competencies?

- yes

- no

- partially

13) Do you think that distance education platforms provide an opportunity to assess the real knowledge of students and ensure quality control of knowledge?

- yes

- no

- other

14) What kind of activity is a priority during the COVID19 pandemic?

- educational

- $\quad$ scientific

- methodical

- educational

The survey was conducted online using Google forms, which allowed to cover most of the respondents during the pandemic. The number of respondents who took part in the survey was a total of 173 teachers from two educational institutions. 103 of them are respondents from Hlukhiv National Pedagogical University named after Oleksandr Dovzhenko, which is $72 \%$ of the total number of university teachers. Accordingly, 70 respondents from Lviv State University of Life Safety, which is $18 \%$ of the total number of university teachers. This study was conducted exclusively among university teachers.

\begin{tabular}{|c|c|c|c|}
\hline \multicolumn{2}{|c|}{$\begin{array}{l}\text { Oleksandr Dovzhenko } \\
\text { Hlukhiv National Pedagogical } \\
\text { University }\end{array}$} & \multicolumn{2}{|c|}{$\begin{array}{l}\text { Lviv State University of Life } \\
\text { Safety }\end{array}$} \\
\hline \multicolumn{4}{|c|}{ Number of survey participants } \\
\hline \multicolumn{2}{|c|}{103 respondents } & \multicolumn{2}{|c|}{70 respondents } \\
\hline \multicolumn{4}{|c|}{ Gender } \\
\hline men & women & men & women \\
\hline $\begin{array}{l}27 \\
\text { respondents }\end{array}$ & $\begin{array}{l}76 \\
\text { respondents }\end{array}$ & $\begin{array}{l}38 \\
\text { respondents }\end{array}$ & $\begin{array}{l}32 \\
\text { respondents }\end{array}$ \\
\hline \multicolumn{4}{|c|}{ Age of respondents } \\
\hline $\begin{array}{l}20-30 \text { years - } \\
31-40 \text { years - } \\
41-50 \text { years - } \\
51-60 \text { years - } \\
61-70 \text { years - }\end{array}$ & & $\begin{array}{l}20-30 \text { years } \\
31-40 \text { years } \\
41-50 \text { years } \\
51-60 \text { years } \\
61-70 \text { years }\end{array}$ & \\
\hline
\end{tabular}

\section{Results}

In connection with the introduction of quarantine on March 12, 2020, in connection with the pandemic, Ukrainian universities switched to distance learning. As is often the case, a new challenge has become an unbearable burden for some, and an opportunity for development for others.

We will consider in our article whether Ukrainian educational institutions were ready to move from full-time/part-time to distance education today to tomorrow, and what problems arose. First, you need to establish distance learning - a form of education or the use of technology? [13].

When talking about distance learning, we need to distinguish between two similar terms: "distance form of education" and "use of distance technology" in different forms of education (full-time, part-time) [14].

Distance education is an opportunity to study and receive the necessary knowledge remotely from the school at any convenient time. Citizens who have secondary, vocational, higher education, as well as those who can remotely perform the necessary tasks with the help of educational technologies can study remotely in Ukraine. The learning process is based on the use of various means of communication. Upon completion of such training, students receive appropriate certificates and diplomas [16].

Distance education is very important for those who live in hard-to-reach settlements, people with disabilities, gifted children and boys and girls who are able to master the material on their own, for students who cannot attend classes due to family circumstances, and citizens of Ukraine. living abroad. In this form of education is an important element of self-discipline and self-organization of the student.

When we talk about "distance technology in education" we mean specific platforms and tools (eg, Moodle, Google Classroom, Zoom, Skype, Google Suite / Docs, etc.) that allow students and teachers to communicate, perform and test tasks, control attendance, organize semester control and certification, etc. Such technologies, depending on the country, university, and discipline being studied, can be integrated at any stage of the course. Here the teacher's initiative to implement such technologies, the readiness of students to use them, and the technical ability of both parties to apply these technologies are important.

Prior to quarantine, only some Ukrainian universities could teach distance (as a form of education and/or they must have a special license), and in fact, all universities used distance learning to some extent. Rapid informatization and digitalization of society actualize the use of such technologies as video conferencing or learning management systems (Learning Management Systems LMS), etc.

Therefore, one of the questions in our questionnaire was: "What communication tools and technologies do you use during the COVID-19 pandemic in your educational 
institution?". This question was answered by all respondents. It should be noted that the main information tool used by our respondents was ZOOM $(100 \%$ of responses), followed by Google services (53\%), followed by the use of E-mail (37\%), Viber (8\%), and another $2 \%$. Of course, the only and global problem for Ukraine is a high-quality Internet connection (especially for villages and remote areas that do not have and/or have partial coverage). Universities faced this problem because most of the students were villagers, and during the quarantine, they left the campuses and moved to their homes.

Language and live communication play a big role in our lives. We need constant communication with each other, with neighbors, family, etc. The pandemic has partially taken away this opportunity from us. After all, we were all forced to lock ourselves in our homes to reduce the risk of the disease spreading. How has this affected the teaching community? As can be seen from Figure 1, due to increased digitalization, most respondents said that their level of communication with colleagues (51.4\%) and students (31.2\%) did not change but remained at the previous level, increased in relation to students (47.3\%) (sending assignments, checking them, lectures, defense of term papers, etc.), in relation to colleagues increased by $15.6 \%$. Some respondents say that their level of communication with each other (32.5\%) and in relation to students (21.3\%) has decreased.

The priority of higher education is to provide quality educational services.

Education is the spiritual face of man, which is formed under the influence of moral and spiritual values, which is the property of its cultural circle, as well as the process of education, self-education, influence, polishing. The main thing is not the amount of knowledge, but its combination with personal qualities, the ability to independently dispose of it [7].

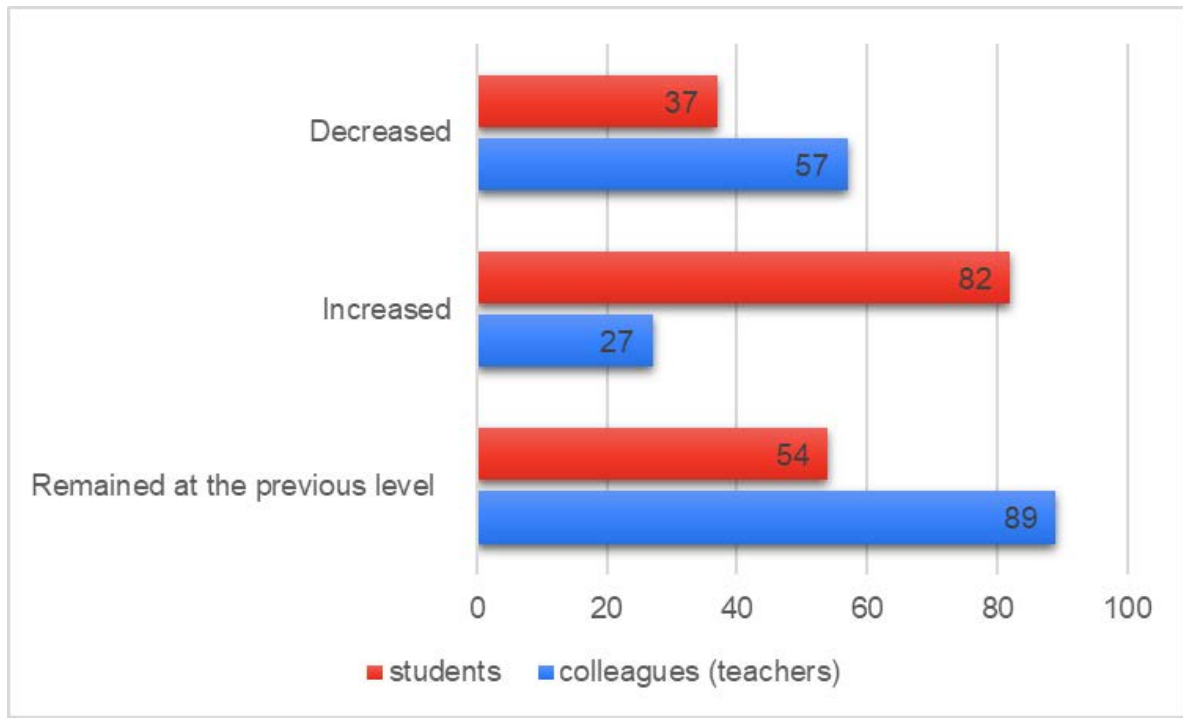

Figure 1. How did the level of your communication with colleagues/students change during the quarantine related to COVID-19?

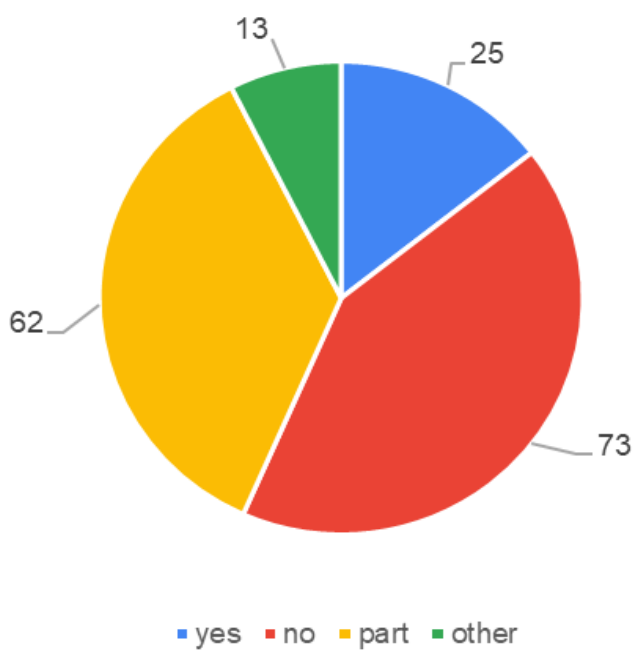

Figure 2. Do you think that distance education can provide practical skills and competencies and ensure quality control of knowledge? 
In addition to basic knowledge, students need practical skills and personal qualities (competencies) that will help them compete successfully in modern society.

The complex concept includes the acquisition of academic knowledge, effective socialization of students, emotional interaction with others, the development of skills of caring for others, solving complex problems, and much more.

Researchers [5, 9, 14] named 16 most important skills for students' XXI century, which is divided into three groups: fundamental knowledge (literacy), skills (skills), personal (personal) qualities.

Whether these essential skills provide students with a complete distance education regime was one of the main questions of our study. The results are presented in Figure 2: 25 respondents answered that no (14.4\%); 73 respondents answered "no" - 42.1\%; 62 respondents answered "partially" - 35.8\%; 13 respondents answered "other". As we can see, most teachers are inclined to think that the transition to full distance education makes it impossible to receive full feedback from their students, and it is impossible to trace how they apply their theoretical knowledge in practice.

In our opinion, the combination of online \& offline education (as a type of distance education) will provide an opportunity to develop practical skills and consolidate the acquired knowledge better than just using online education.
This is especially true for specialties of a natural nature, as well as for future teachers. Since these specialties require the practical application of the acquired knowledge in laboratories, research institutions, etc.

On April 27, 2020, the Ministry of Education and Science of Ukraine sent a letter to all educational institutions "on certain issues of university activities during quarantine" (№ 1 / 9-224 of April 27, 2020) (kmu.gov.ua, 2020). According to this document, there have been partial changes, in/about:

- class schedule for the quarantine period.

- $\quad$ performing research and preparing publications.

- professional development activities mastering distance learning technologies.

- additional development of methodological support for disciplines for distance learning.

- conducting individual consultations and additional control measures, etc.

Based on this document, we asked our respondents questions about the management of the school during the quarantine (Fig. 3). Did they observe changes, in particular, 86 (49.7\%) people answered that the educational, educational and scientific component of teachers' activities was optimized; 56 (32.3\%) respondents said that there was a partial decentralization in the educational process; remained unchanged - this opinion of 28 people (16.1\%); the rest -3 respondents $(1.7 \%)$.

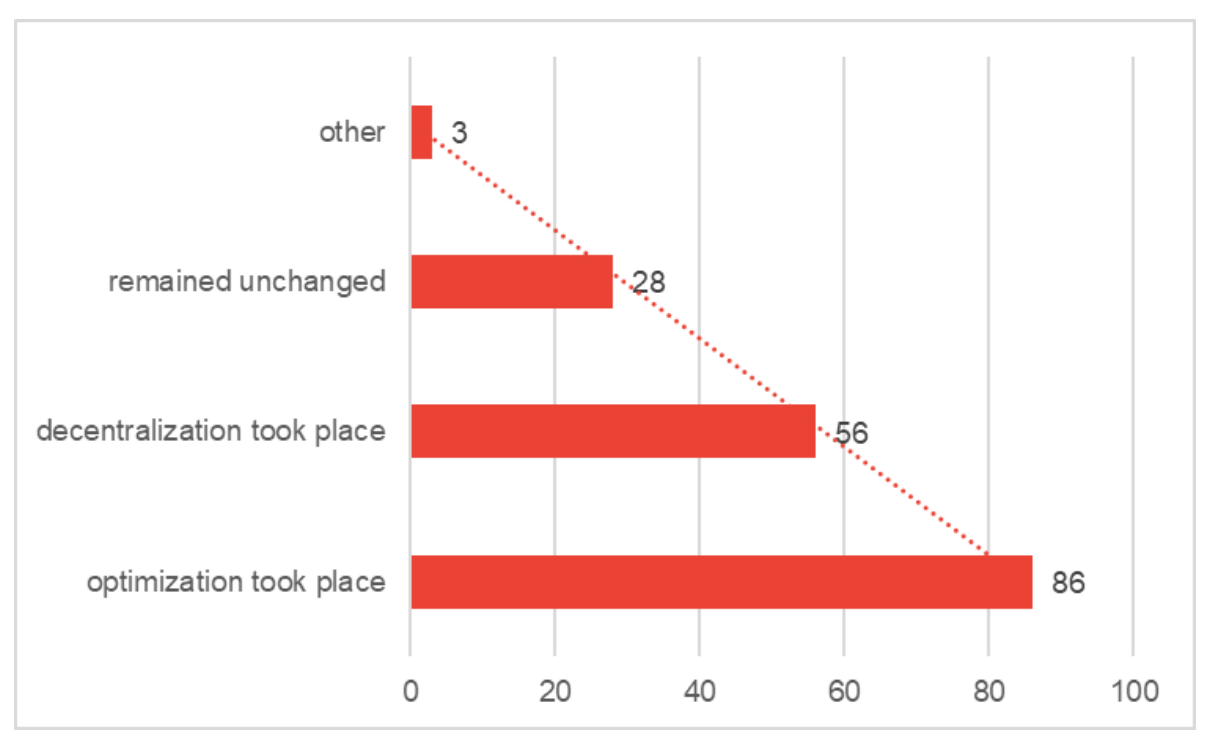

Figure 3. What changes have taken place in the management system of your school during the COVID-19 pandemic 


\section{Discussion}

Our study provides the first summary data on the educational process in Ukraine during the outbreak of the COVID-19 pandemic and the need for urgent implementation of distance education in educational institutions.

We analyzed in the legal framework of the Ministry of Education and Science of Ukraine, online discussion of the problems of distance education on a special portal mon.gov.ua/ua/osvita/visha-osvita/distancijna-osvita. Also, the only information we could analyze in addition to the main orders, the legal framework of this period from the Ministry of Education and Science of Ukraine, were reports of deputy ministers, leading experts of the Academy of Sciences of Ukraine, directors of regional education departments on distance education during the quarantine. They emphasized both the pros and cons. This contributed to the formation of the main questions for our questionnaire, regarding distance education during the quarantine.

Our study was based on the results of UNESCO (UNESCO.org, 2020) and leading educational institutions in Europe and America [1, 3, 4, 6, 8]. In particular, we fully agree with Nasir Mustafa [10] that most educational institutions are the center of the city's economic development and that quarantine measures for a college or university have affected the city's status as a result of the pandemic $[11,15]$. However, we want to emphasize that in Ukraine this is typical only for small towns (for example, one of the universities that took part in the study is Hlukhiv National University named after Oleksandr Dovzhenko). Because for a small town, the university/college, namely its students, are the main economic investors in infrastructure. For a large city, even in the absence of a small number of students, this will not be the case, as most of them are local. This is, for example, Lviv State University of Life Safety.

The main problem faced by the education of Ukraine is, first, the aging of scientific staff (which, unfortunately, is exceedingly difficult to navigate with modern IT technologies and programs). Unfortunately, in our study, we covered only a few leading universities in Ukraine, but this is a very real problem for the whole state and universities. Therefore, despite the pandemic, and the quarantine restrictions of the Council of Young Scientists in Ukraine, both at the Ministry of Education and at each university as a whole unite efforts to promote science, research, research papers, grants, government procurement projects. After all, it is through joint efforts that the development of education and science in the state can be achieved.

We also noted that the main staff in the educational and scientific environment are women, who mainly form the community of universities. Many scientific, pedagogical, and pedagogical employees of higher education institutions of Ukraine are women. And when the doors of schools and kindergartens were closed for quarantine, many teachers suffered the same fate as other Ukrainian women - working from home, raising children, and organizing home life. In Ukraine, most of this work continues to be performed mainly by women. Although over the past five years the number of those who believe that women should take care of the household and raise children has decreased, 83\% of people still believe that the most important task of a woman is to take care of home and family, and a man - to earn money (75\%). The issue of gender equality is still acute in our society, and universities are no exception.

So, the coronavirus has really raised many important issues in higher education. But to turn problems into opportunities, universities as well as education departments need to understand how effective distance learning is implemented (including receiving quality feedback from both teachers and students). Because distance learning is now driven by circumstances, when in fact it increases the availability of education, blended learning, a combination of distance and face-to-face forms, may well be our future.

However, to do this, today we must actively work on the lessons learned and ensure the quality of such education.

\section{Conclusions}

1. The Covid-19 pandemic has changed the worldview of society in all directions, both in the educational environment and social, economic, psychological, etc.

2. The introduction of distance education both in the world and in Ukraine has its pros and cons. In particular: the introduction of remote technologies depends primarily on the initiative of the teacher to implement such technologies, as well as on the willingness of students to use them and the technical ability of both parties to use these technologies (because our country has faced the problem of Internet coverage).

3. We found that in the era of information technology, the level of communication, both interpersonal and with students, has not changed among the respondents.

4. It is established that almost all teachers who took the survey believe that distance education does not provide students with practical skills, competencies after graduation. That is, the student who has received theoretical knowledge is not able to practically implement it.

5. Distance education from the point of view of management and administrative activity is more expedient, it gives educational institutions more opportunities for decentralization and optimization in work. 


\section{REFERENCES}

[1] "10 March 2020 - Covid-19 Statement from the Department of Education and Skills - Department of Education and Skills".

https://www.education.ie/en/Press-Events/Press-Releases/2 020-press-releases/covid-19-statement-10mar20.html. (accessed April 06, 2020)

[2] "Half of world's student population not attending school: UNESCO launches global coalition to accelerate deployment of remote learning solutions". UNESCO. https://en.unesco.org/news/half-worlds-student-populationnot-attending-school-unesco-launches-global-coalition-acce lerate. (accessed March 29, 2020)

[3] "Situational Report No.6 of the National Task Force (NTF) for COVID-19". National Disaster Risk Reduction and Management Council. 6 April 2020. http://ndrrmc.gov.ph/at tachments/article/4036/sitrep_no6_re_national_task_force_ for_coronavirus_disease_2019_issued_06_april_2020_4PM .pdf (accessed April 8, 2020)

[4] Barrett S. "Coronavirus on campus: College students scramble to solve food insecurity and housing challenges". CNBC.

https://www.cnbc.com/2020/03/23/coronavirus-on-campusstudents-face-food-insecurity-housing-crunch.html (accessed March 23, 2020)

[5] Brooks S.K., Webster R.K., Smith L.E., et al. The psychological impact of quarantine and how to reduce it: rapid review of the evidence. vol 395. pp. 912-20, 2020. doi:10.1016/SO140-6736(20)30460-8 (accessed March 20, 2020)

[6] Giuffrida A., Tondo L., Beaumont P. "Italy orders closure of all schools and universities due to coronavirus". The Guardian. ISSN 0261-3077. https://www.theguardian.com/ world/2020/mar/04/italy-orders-closure-of-schools-and-uni versities-due-to-coronavirus (accessed March 06, 2020)

[7] Goncharenko S. Ukrainian pedagogical dictionary. Kiev. "Lybid", 1997. 366 p. (in Ukraine)

[8] Jamerson J., Mitchell J. "Student-Loan Debt Relief Offers Support to an Economy Battered by Coronavirus". Wall
Street Journal. ISSN 0099-9660. https://www.wsj.com/artic les/student-loan-debt-relief-offers-support-to-an-economy-b attered-by-coronavirus-11584735842 (accessed March 23, 2020)

[9] Libanova E., Tsymbal O., Yarosh O., Lisohor L. Transition to the youth labor market of Ukraine: results of the international study "School-to-worktransitionsurveys" in Ukraine in 2013 and 2015. - International Labor Office. Geneva: MOP, 2016. 112 p. (in Ukraine)

[10] Nasir M. Impact of the 2019-20 coronavirus pandemic on education https://www.researchgate.net/publication/340849956_Impa ct_of_the_2019-20_coronavirus_pandemic_on_education doi: 10.13140/RG.2.2.27946.98245 (accessed April 22, 2020)

[11] OCDE. A helping hand: Education responding to the coronavirus pandemic. Retrieved the 24.03.2020 from https://oecdedutoday.com/education-responding-coronaviru s-pandemic/

[12] Resolution of the Cabinet of Ministers of Ukraine "On prevention of the spread of coronavirus COVID-19 on the territory of Ukraine" № 211 (11.03.2020).https://www.kmu .gov.ua/npas/pro-zapobigannya-poshim110320rennyu-na-te ritoriyi-ukrayini-koronavirusu-covid-19 (accessed April 2, 2020)

[13] Six problems of Ukrainian higher education identified by quarantine http://osvita.ua/vnz/74767/ (accessed May 22, 2020)

[14] Tilikina N.V., Krymova M.O. Skills of the XXI century as a condition for young people to enter the labor market Investments: practice and experience № 5 - 6/2020 p. 21-28 doi: 10.32702/2306-6814.2020.5-6.21 (in Ukraine)

[15] United Nations Educational, Scientific and Cultural Organization. COVID-19 educational disruption and response. https://en.unesco.org/themes/education-emergenc ies/coronavirus-schoolclosures (accessed May 19, 2020).

[16] Youth of Ukraine - 2018: results of a representative sociological study / Ministry of Youth and Sports of Ukraine. Ternopil: LLC "Terno-graf", 2018, 72 p. (in Ukraine) 